\title{
Cloning and Expression of an Adhesin Antigen of Streptococcus sanguis G9B in Escherichia coli
}

\author{
By BURTON ROSAN, * CAROL T. BAKER, GENEVIEVE M. NELSON, \\ RICHARD BERMAN, RICHARD J. LAMONT AND DONALD R. DEMUTH \\ University of Pennsylvania, School of Dental Medicine, \\ Departments of Microbiology and Biochemistry, Philadelphia, PA 19104, USA
}

(Received 22 June 1988; revised 25 November 1988; accepted 5 December 1988)

\begin{abstract}
A genomic library of Streptococcus sanguis, strain G9B, was constructed and expressed in Escherichia coli using a $\lambda$ gt11 expression vector. The amplified library was probed with polyclonal anti-G9B IgG and 13 antigen-positive clones were isolated. A lysate of one clone, designated PP39, absorbed the adhesion-inhibitory activity of anti-G9B IgG. This clone contained an insert of approximately $2000 \mathrm{bp}$ and expressed unique 200 and $53 \mathrm{kDa}$ proteins that reacted with monospecific anti-adhesin antibody. The $200 \mathrm{kDa}$ protein also reacted with anti- $\beta$ galactosidase $\mathrm{IgG}$, indicating that it is a fusion protein of which $84 \mathrm{kDa}$ represents the streptococcal adhesin. The 84 and $53 \mathrm{kDa}$ proteins are similar in size to the major polypeptides in a streptococcal antigen complex which is associated with the adhesion of G9B to salivacoated hydroxyapatite. The $53 \mathrm{kDa}$ fragment may result from post-translational cleavage of the recombinant polypeptide.
\end{abstract}

\section{INTRODUCTION}

The binding of Streptococcus sanguis to the salivary pellicle that coats tooth surfaces is believed to be the first phase of dental plaque formation (Gibbons \& van Houte, 1971; Hamada $\&$ Slade, 1980). Saliva-coated hydroxyapatite (SHA) is used as an in vitro model for investigating bacterial attachment to the pellicle and for characterizing bacterial adhesins. Most of these studies suggest that attachment of $S$. sanguis to SHA involves more than one adhesin and salivary receptor (Cowan et al., 1986, 1987; Doyle et al., 1982; Gibbons et al., 1983; Morris \& McBride, 1984).

With the exception of a study by Liljemark \& Bloomquist (1981), in which a partially purified cell wall extract of $S$. sanguis was found to block attachment of whole bacteria to SHA, most studies have relied on indirect methods to demonstrate the presence of adhesins in extracts of the streptococcal surfaces (Bergey et al., 1986; Curtiss et al., 1985; Douglas \& Russell, 1984; Elder \& Fives-Taylor, 1986; Fachon-Kalweit et al., 1985; Fives-Taylor, 1982; Fives-Taylor \& Thompson, 1985; Morris et al., 1985, 1987). The role of fimbriae and/or fibrils (Handley et al., $1985)$ has been explored by several groups. Fives-Taylor \& Thompson (1985) isolated a number of non-adherent mutants of $S$. sanguis, strain FW213, in which the fimbriae were absent. In one of the mutants a $150 \mathrm{kDa}$ antigen associated with the fimbriae was also missing (Elder \& FivesTaylor, 1986). Morris et al. $(1985,1987)$ isolated hydrophilic variants of $S$. sanguis which did not adhere as well as the parent hydrophobic strain. These variants did not have the fibrils found in the parent strain and apparently had very few proteins in their cell wall compared to the parent (Morris et al., 1987). In studies comparing $S$. sanguis G9B with a non-adherent mutant ( $\mathrm{Adh}^{-}$) (Lamont et al., 1988a,b), no differences in fibrils between parent and mutant were observed

Abbreviations: HA, hydroxyapatite; SHA, saliva-coated hydroxyapatite. 
(P. S. Handley, personal communication). Ganeshkumar et al. (1988) showed that a $36 \mathrm{kDa} S$. sanguis protein cloned in Escherichia coli blocked attachment of the organism to SHA. This protein did not react with anti-fibril serum, although it appeared to be present on the surface of the streptococcus. The results of these studies make it unclear whether it is the fimbriae or fibrils per se, or a component of these appendages or some other cell wall component, which is responsible for the specificity of attachment to SHA.

In recent studies (Lamont et al., 1988b), we have identified an antigen(s) which is associated with the specific attachment of $S$. sanguis G9B to SHA. We refer to this antigen(s) as the $80 \mathrm{kDa}$ complex because a polypeptide of this size is the dominant of three antigens detected by immunoblotting. In order to obtain the quantities of this antigen necessary for further characterization, we shotgun cloned the G9B chromosome into $E$. coli using the $\lambda \mathrm{gt} 11$ phage expression vector (Young \& Davis, 1983; Young et al., 1985). The goal of these initial studies was to isolate a clone expressing the $80 \mathrm{kDa}$ antigen from the $E$. coli library.

\section{METHODS}

Organisms and media. S. sanguis strain G9B was originally isolated from dental plaque and is a biotype I (Facklam, 1977) and serotype 1 strain (Rosan, 1973). Immediately after isolation the cultures were lyophilized and frozen in trypticase (BBL Microbiology Systems)/yeast extract (Difco) medium (TY) with $15 \%(\mathrm{v} / \mathrm{v})$ glycerol. The organisms have been subcultured only infrequently to maintain stocks. The bacteria were grown in TY with $0.5 \%$ $(\mathrm{w} / \mathrm{v})$ glucose as a carbon source at $37^{\circ} \mathrm{C}$ for $18 \mathrm{~h}$ (Rosan et al., 1982). E. coli strain Y1090 (AlacU169 proA ${ }^{+}$Alon araD139 strA supF $[\operatorname{trp} C 22:: \operatorname{Tn} 10]$ hsdR $\left.h s d M^{+}(\mathrm{pMC} 9) ; \mathrm{pMC} 9=\mathrm{pBR} 322-l a c I^{+}\right)$was obtained from Promega Biotec. The strain was maintained on Luria-Bertani (LB) broth supplemented with $50 \mu \mathrm{g}$ ampicillin ml-1 (Young \& Davis, 1983; Young et al., 1985).

Barbital extraction. Streptococcal surface molecules were extracted by shaking in 2 mM-barbital buffer, $\mathrm{pH} 8 \cdot 6$, as reported previously (Lamont et al., 1988a).

Immunoblotting. SDS-PAGE gels $(10 \%, \mathrm{w} / \mathrm{v}$, acrylamide) were run (Laemmli, 1970), blotted onto nitrocellulose (Towbin et al., 1979) and probed with antibody as described previously (Lamont $e$ t al., 1988a, b). Samples were heated at $100{ }^{\circ} \mathrm{C}$ for $3 \mathrm{~min}$ in $0.05 \mathrm{M}$-Tris/ $\mathrm{HCl}$, pH 8.6 , containing $2 \%(\mathrm{w} / \mathrm{v}) \mathrm{SDS}, 10 \%(\mathrm{v} / \mathrm{v})$ glycerol, and $5 \%(\mathrm{v} / \mathrm{v})$ 2-mercaptoethanol prior to electrophoresis.

Antisera. Antisera were produced in rabbits against formalinized whole cells of $S$. sanguis $\mathrm{G} 9 \mathrm{~B}$ using procedures described previously (Rosan, 1973, 1976, 1978). The concentration of the antisera was adjusted to obtain optimal visualization of as many antigens as possible by immunoblotting. The $\mathrm{IgG}$ fractions of normal rabbit sera and the antisera used in these studies were purified by affinity chromatography over a protein A-Sepharose 4B column (Lamont et al., 1988a). All of the studies reported here used the same IgG pools.

Antibodies reacting specifically with the native $80 \mathrm{kDa}$ antigen complex were prepared by affinity purification from immunoblots (Olmsted, 1981 ; Lamont et al., 1988a). Polyacrylamide gels of $S$. sanguis G9B barbital extract were run and blotted onto nitrocellulose as described above except that SDS was omitted from all buffers and the samples were not boiled. A strip of the transfer was developed with antiserum to the denatured $80 \mathrm{kDa}$ antigen (Lamont et al., 1988a). The strip was aligned with the rest of the blot and the band containing the native $80 \mathrm{kDa}$ antigen complex was excised. This strip was incubated with G9B antiserum diluted 1 in 100 in PBS (phosphate buffered saline: $0.01 \mathrm{M}$-sodium phosphate, $\mathrm{pH} 7.4,0.15 \mathrm{M}-\mathrm{NaCl})$ containing $0.1 \%(\mathrm{v} / \mathrm{v})$ Tween 20 . After washing, the antibody bound to the strip was eluted with $0.05 \mathrm{M}$-glycine/ $\mathrm{HCl}$ buffer, $\mathrm{pH} 2.3$, and dialysed against $0.05 \mathrm{M}$ Tris in $0.15 \mathrm{M}-\mathrm{NaCl}, \mathrm{pH} 8.6$. Monoclonal antibody (IgG) against $\beta$-galactosidase was obtained from Promega.

Absorption of antibodies with $E$. coli. Antibodies cross-reacting with $E$. coli were removed from streptococcal antibody preparations by absorption with $E$. coli lysates obtained by freeze-thawing (Maniatis et al., 1982). The lysate $(10 \mathrm{mg})$ was dissolved in $5 \mathrm{ml}$ PBS and adsorbed to nitrocellulose filters $(8.5 \mathrm{~cm}$ diameter) for $1 \mathrm{~h}$ at room temperature with shaking. The filters were washed with PBS and treated with blocking buffer [PBS with $10 \%(\mathrm{v} / \mathrm{v})$ new-born calf serum and $0.2 \%(\mathrm{v} / \mathrm{v})$ Triton X-100]. After rinsing with PBS, the filters were used immediately or stored at $-20^{\circ} \mathrm{C}$ after drying on Whatman filter paper. The IgG to be absorbed was diluted to $7 \mu \mathrm{g} \mathrm{ml}^{-1}$ in blocking buffer. Volumes of $5 \mathrm{ml}$ were added to the nitrocellulose filters and shaken for $45 \mathrm{~min}$ at room temperature. The absorbed IgG was removed and reabsorbed five times before use.

Construction of the S. sanguis genomic library. To obtain genomic DNA, S. sanguis G9B was grown overnight in TY, $1 \mathrm{ml}$ was subcultured in the same medium $(250 \mathrm{ml})$ containing $200 \mu \mathrm{Ci}\left[{ }^{3} \mathrm{H}\right]$ thymidine (Amersham) and the cells were grown to early exponential phase $\left(\mathrm{OD}_{660} 0 \cdot 3\right)$. The cells were harvested and washed once in TES (10 mM Tris/ $\mathrm{HCl} \mathrm{pH} \mathrm{8,} 100 \mathrm{~mm}-\mathrm{NaCl}, 1 \mathrm{~mm}-\mathrm{EDTA}$ ) and lysed with $1 \mathrm{ml}$ mutanolysin (525 units) (Sigma) containing 250 units $T_{1}$ RNAase (Sigma). The solution was heated at $80^{\circ} \mathrm{C}$ for $15 \mathrm{~min}$ to destroy DNAase.

A genomic library was constructed in $\lambda$ gtl1 (Promega Biotech) according to established procedures (Young \& Davis, 1983; Young et al., 1985). In brief, $100 \mu \mathrm{g}$ DNA was sonicated and 2-9 $\mathrm{kb}$ fragments were isolated by 
elution from low-melting-point agarose (Sea Plaque, FMC Bioproducts) following electrophoresis. Internal EcoRI sites were methylated using EcoRI methylase (NE Biolabs) and fragments were made blunt-ended with T4 DNA polymerase as described by Maniatis et al. (1982). The DNA was dissolved in $4.5 \mu 1$ of a $100 \mathrm{~mm}-\mathrm{Tris}, \mathrm{pH} 7.5$, buffer containing $100 \mathrm{~mm}-\mathrm{MgCl}_{2}, 100 \mathrm{mM}-\mathrm{DTT}, 4 \cdot 5 \mu \mathrm{g}$ EcoRI linkers, $10 \mathrm{~mm}-\mathrm{ATP}$ and 2 units T4 ligase; the final volume was $46.4 \mu \mathrm{l}$. Cohesive ends were made by digestion with EcoRI (Bethesda Research Laboratories). Linkers were separated by passage through a Sepharose $\mathrm{Cl}-4 \mathrm{~B}$ column $(5 \mathrm{ml})$ which had been calibrated with $\left[{ }^{3} \mathrm{H}\right]$ thymidine-labelled fragments of $S$. sanguis DNA. The final yield was approximately $1 \mu \mathrm{g}$ of $2-9 \mathrm{~kb}$ fragments of $S$. sanguis DNA. Ligation with $\lambda$ gtll arms and in vitro packaging were carried out according to the manufacturer's specifications. The library was plated on LB plates containing $50 \mu \mathrm{g}$ ampicillin $\mathrm{ml}^{-1}$ and $160 \mu \mathrm{g}$ isopropyl $\beta$-D-thiogalactopyranoside $\mathrm{ml}^{-1}$ (IPTG: Boehringer Mannheim) with $0 \cdot 7 \%(\mathrm{w} / \mathrm{v})$ semi-solid top agar containing IPTG as well as $400 \mu \mathrm{g}$ 5-bromo-4-chloro-3-indolyl $\beta$-D-galactopyranoside $\mathrm{ml}^{-1}$ (X-Gal, Sigma) as an indicator of $\beta$-galactosidase activity. The plates were incubated overnight at $37^{\circ} \mathrm{C}$.

Screening libraries with antibody. A nitrocellulose disk was applied to plates containing 400-500 plaques and incubated for $15 \mathrm{~min}$ at room temperature. The disks were marked to allow for future realignment. The nitrocellulose was washed for $30 \mathrm{~min}$ with $5 \mathrm{ml}$ blocking buffer and incubated with $5 \mathrm{ml}$ of the absorbed anti-G9B $\mathrm{IgG}\left(7 \mu \mathrm{g} \mathrm{m}^{-1}\right)$ for $1 \mathrm{~h}$ with shaking. After washing three times, the primary antibody reaction was detected as described above for immunoblots.

Antigen-positive plaques were picked, diluted in $100 \mu \mathrm{l}$ phage dilution buffer $(100 \mathrm{~mm}-\mathrm{NaCl}, 10 \mathrm{~mm}-\mathrm{Tris}$, $\mathrm{pH} 7.9,10 \mathrm{~mm}-\mathrm{MgSO}_{4}$ ), mixed with an equal volume of the indicator strain and plated on semi-solid agar (Maniatis et al., 1982). After overnight growth at $37^{\circ} \mathrm{C}$, the soft agar containing nearly confluent plaques was scraped into centrifuge tubes and shaken with $0.5 \mathrm{ml}$ chloroform at $37^{\circ} \mathrm{C}$. The phage were recovered by centrifugation at $5875 \mathrm{~g}$ at $10^{\circ} \mathrm{C}$.

Recovery of expressed protein. The concentration of phage and host $E$. coli was adjusted to obtain nearly confluent lysis on LB plates containing ampicillin and IPTG. The semi-solid agar was scraped into a centrifuge bottle and $0.1 \mathrm{ml}$ chloroform added for each plate used. Following incubation at $37^{\circ} \mathrm{C}$ for $15 \mathrm{~min}$ the lysate was centrifuged at $4000 \mathrm{~g}$ for $10 \mathrm{~min}$ at $4{ }^{\circ} \mathrm{C}$ to remove agar and residual cells. The supernatant was centrifuged at $107000 \mathrm{~g}$ for $2 \mathrm{~h}$ to remove phage particles, dialysed against $\mathrm{H}_{2} \mathrm{O}$, and lyophilized.

Characterization of recombinant clones. The phage DNA and control $\lambda \mathrm{gt} 11 \mathrm{DNA}$ were recovered by $\mathrm{CsCl}$ density-gradient centrifugation (Maniatis et al., 1982).

Adhesion assay and antibody inhibition of adhesion. The adhesion assay has been described previously (Eifert $e t$ al., 1984). In brief, $\left[{ }^{3} \mathrm{H}\right]$ thymidine-labelled bacteria suspended in buffered $\mathrm{KCl}\left(2 \mathrm{mM}-\mathrm{K}_{2} \mathrm{HPO}_{4}, 5 \mathrm{mM}-\mathrm{KCl}, 1 \mathrm{mM}-\right.$ $\mathrm{CaCl}_{2}, \mathrm{pH}$ ) were incubated with SHA or control uncoated hydroxyapatite (HA). Samples of the cells in equilibrium with the beads were removed to determine the number of free cells; after washing, the beads with attached bacteria were also removed. The numbers of free and bound cells were determined by scintillation spectroscopy.

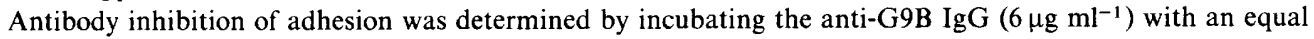
volume of $\left[{ }^{3} \mathrm{H}\right]$ thymidine-labelled G9B cells $\left(2 \times 10^{9}\right.$ cells $\left.\mathrm{ml}^{-1}\right)$ for $18 \mathrm{~h}$ at $4{ }^{\circ} \mathrm{C}$ with continuous rotation. The mixture was centrifuged $\left(7000 \mathrm{~g}, 10 \mathrm{~min}, 4^{\circ} \mathrm{C}\right)$ and the cells washed once in buffered $\mathrm{KCl}$. The cell pellet was suspended in the original volume of $\mathrm{KCl}$ and sonicated for $15 \mathrm{~s}$ prior to use in the adhesion assay. The final

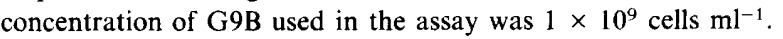

Absorption of adhesion-inhibitory activity from S. sanguis antibodies. The expressed proteins were tested for adhesin activity by absorption of adhesion-inhibitory activity from the anti-G9B IgG. The proteins were dissolved in buffered $\mathrm{KCl}$ and anti-G9B $\mathrm{IgG}\left(6 \mu \mathrm{g} \mathrm{ml}^{-1}\right)$ was added. The mixture was rotated overnight at $4{ }^{\circ} \mathrm{C}$ and any resulting precipitate removed by centrifugation $\left(10000 \mathrm{~g}, 20 \mathrm{~min}, 4^{\circ} \mathrm{C}\right)$. The supernatant containing absorbed antibody was collected and examined for adhesion-inhibitory activities as described above.

\section{RESULTS}

\section{Identification of clones containing $S$. sanguis antigens}

When screened for $\beta$-galactosidase activity, approximately $50 \%$ of the plaques were colourless, indicating insertional inactivation by $S$. sanguis DNA of the gene encoding $\beta$ galactosidase. Initially 3000 recombinant plaques were screened with anti-G9B IgG. Thirteen plaques expressed proteins which reacted to some extent with the antibody. Thus, approximately $0.5 \%$ of the recombinants were producing detectable $S$. sanguis antigens. The antigen-positive plaques were amplified and each was checked for $\beta$-galactosidase activity by growth on LB ampicillin agar containing IPTG and X-Gal. Antigen production was confirmed by seeding a lawn of $E$. coli $\mathrm{Y} 1090$ with $10 \mu 1$ of phage suspension obtained from each of the 


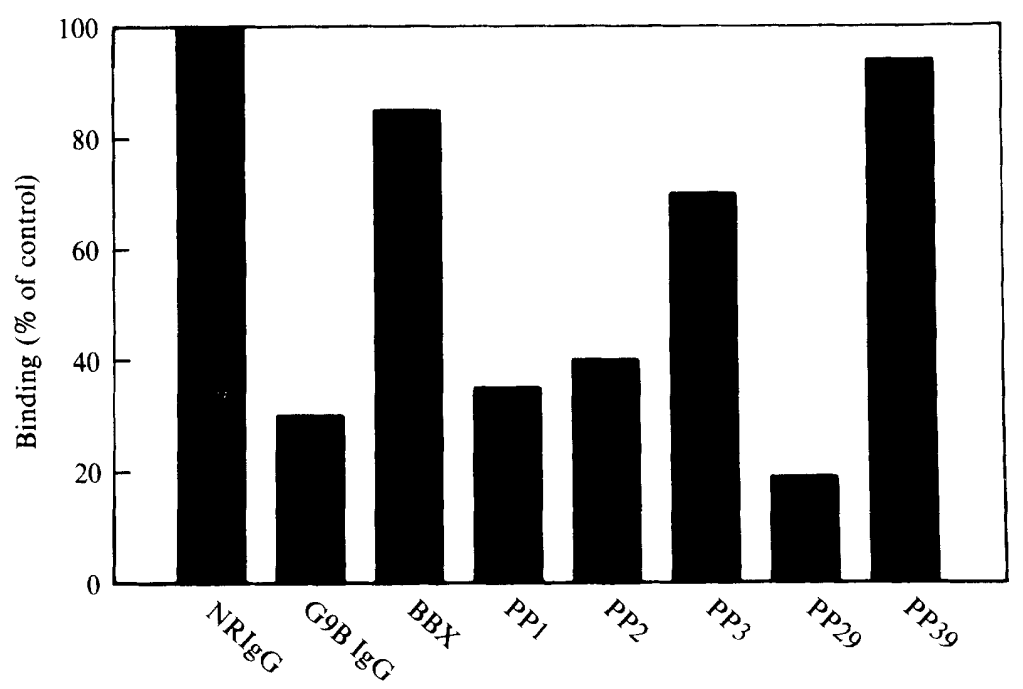

Fig. 1. Absorption of adhesion-inhibitory activity from anti-G9B IgG antibody by antigen-positive plaques: PP1, PP2, PP3, PP29 and PP33 (400 $\mu \mathrm{g}$ protein). NRIgG is normal rabbit IgG $\left(6 \mu \mathrm{g} \mathrm{ml}^{-1}\right)$, G9B IgG is purified anti-G9B IgG $\left(6 \mu \mathrm{g} \mathrm{ml}^{-1}\right)$, BBX is a positive control of anti-G9B IgG $\left(6 \mu \mathrm{g} \mathrm{ml}^{-1}\right)$ absorbed with $400 \mu \mathrm{g}$ protein of barbital extract of G9B. Binding of $S$. sanguis $\mathrm{G} 9 \mathrm{~B}$ to SHA is expressed as a percentage of the value obtained with the NRIgG control: [(percentage of cells bound in test sample) $/($ percentage of cells bound in control) $] \times 100$. The binding of $1 \times 10^{9} \mathrm{G} 9 \mathrm{~B}$ cells treated with NRIgG was $40 \% \pm 5 \%$.

positive plaques; controls from negative plaques and parent phage were included. The positive plaques were subcloned and again screened for antigenic activity. Some plaques which were weakly positive in the initial screening did not react following amplification; others still gave weak reactions with anti-G9B IgG. However, one subclone, PP39, gave a strong reaction in both the initial screening and subsequent amplification. None of the antigen-positive plaques expressed $\beta$-galactosidase activity. The parent $\lambda$ gt 11 plaque was positive for $\beta$-galactosidase and did not react with the anti-G9B IgG.

\section{Absorption of adhesion-inhibitory activity}

Lysates of the antigen-positive plaques were tested for the ability to absorb the adhesioninhibitory activity of anti-G9B IgG; the results are shown in Fig. 1. At the concentration of cells used in these studies, approximately $40 \%$ of the labelled G9B cells adhere to SHA (Eifert et al., 1984). Treating the cells with normal rabbit IgG (NRIgG) did not affect adhesion (Fig. 1). In contrast, treating the cells with anti-G9B IgG (G9B IgG) inhibited attachment by approximately $70 \%$. Inhibition has been shown to be specific for SHA and does not occur if HA is used as the substrate (Rosan et al., 1985). The antibody-inhibitory activity was absorbed with a barbital extract of G9B (BBX), which serves as a positive control for adhesin activity. Of the 13 antigen-producing clones, 11 showed no antibody-absorption activity, one (PP3) absorbed antibody to an extent causing $70 \%$ loss of inhibitory activity, and one (PP39) absorbed antibody to an extent causing $94 \%$ loss of inhibitory activity. The results suggested that PP39 expressed proteins most closely related to the $S$. sanguis adhesin and therefore this clone was selected for further study.

\section{Immunoblots of cloned proteins}

Both parent $\lambda$ gt11 and PP39 lysates were examined by immunoblotting (Fig. 2). PP39 produced unique 200 and $53 \mathrm{kDa}$ proteins which reacted with anti-G9B IgG (absorbed with $E$. coli). This clone also reacted with anti-80 kDa antibodies which inhibited binding of G9B to SHA to the same extent as anti-G9B IgG. No reaction was observed with normal rabbit IgG (not shown). In addition, the $200 \mathrm{kDa}$ antigen reacted with monoclonal anti- $\beta$-galactosidase 
(a)

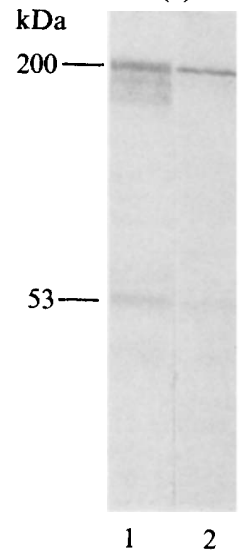

(b)

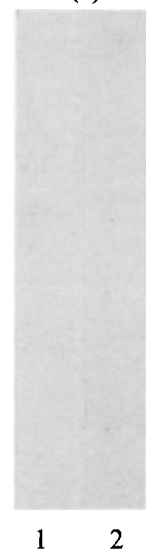

Fig. 2. Immunoblot of plaque lysates. (a) Lysate of PP39 ( $2 \mu \mathrm{g}$ protein); (b) lysate of parent phage $\lambda$ gt 11 $(2 \mu \mathrm{g}$ protein). The blots have been treated with antibody diluted 1 in 100 : lane 1 , anti-G9B; lane 2 , anti$80 \mathrm{kDa}$ antigen complex.

antibodies, indicating that it is a fusion protein produced from the lac promoter and containing antigenic determinants of the lac $Z$ gene product. The anti- $\beta$-galactosidase antibodies reacted with a $116 \mathrm{kDa}$ band (consistent with the size of $\beta$-galactosidase) in the parent $\lambda$ gt 11 lysate (not shown). Thus, PP39 appeared to be producing a fusion protein of $200 \mathrm{kDa}$ and a smaller protein of $53 \mathrm{kDa}$, which could be a breakdown product. Both of these proteins reacted with the monospecific antibodies that inhibit adhesion of G9B to SHA.

\section{Preliminary restriction map of cloned adhesin gene}

Phage DNA isolated from clone PP39 was digested with EcoRI. The resulting fragments, which were separated by agarose gel electrophoresis, indicated that the $S$. sanguis DNA insert contained two internal EcoRI sites. Therefore, a larger fragment was cut with BamHI to yield a $22 \mathrm{~kb}$ fragment that contained the inserted DNA. This fragment was digested with EcoRI, KpnI, HindIII and SstI to map the inserted DNA. Analysis of these DNA fragments resulted in the map shown in Fig. 3. The streptococcal insert DNA is about $2000 \mathrm{~kb}$ in length and contains two internal EcoRI sites upstream of a $K p n I$ site. Expression of the adhesin gene is directed from the lac promoter, indicating that the streptococcal promoter is not contained in this clone.

\section{DISCUSSION}

Investigations of $S$. sanguis adhesion to SHA have been hampered by the difficulty of obtaining large amounts of active surface adhesins from the organism. The production of adhesin and related proteins by recombinant DNA methodologies is one means of obviating this problem. The observations presented in this paper indicate that a $2 \mathrm{~kb}$ DNA insert from $S$. sanguis G9B coding for a protein showing adhesin activity has been cloned and expressed as a fusion protein in $E$. coli. This protein absorbs the SHA adhesion inhibitory activity of G9B IgG. Given that approximately $116 \mathrm{kDa}$ of the fusion protein would represent $\beta$-galactosidase, then the streptococcal protein would be approximately $84 \mathrm{kDa}$. The coding capacity of the insert would be sufficient to code for a protein of this size. The $53 \mathrm{kDa}$ polypeptide may result from post-translational cleavage. Proteins of 80 and $52 \mathrm{kDa}(80 \mathrm{kDa}$ antigen complex) were previously found to be associated with adhesin activity in S. sanguis G9B (Lamont et al., 1988a, b). Further evidence that these cloned proteins are related to the $80 \mathrm{kDa}$ complex is provided by a positive reactivity with monospecific ant $\mathrm{i}-80 \mathrm{kDa}$ antibodies which inhibit adhesion of $\mathrm{G} 9 \mathrm{~B}$ to SHA.

The restriction map of the G9B adhesin gene is distinct from the maps of an adhesin gene 


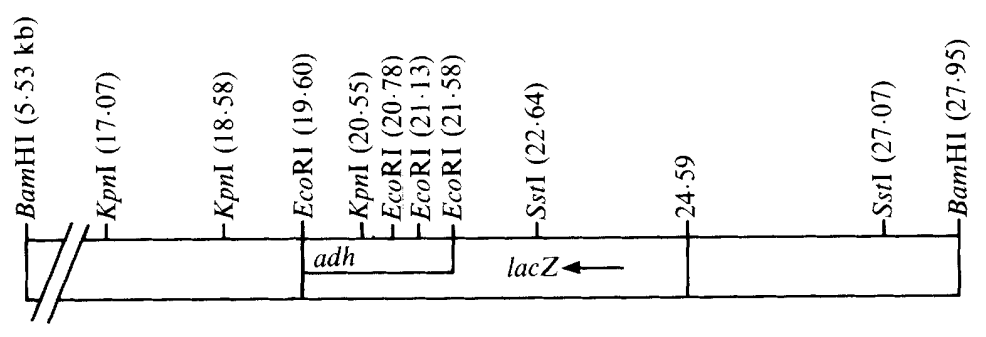

Fig. 3. Partial restriction map of a $22 \mathrm{~kb}$ BamHI fragment containing the segment of adhesin gene $(a d h)$ from $S$. sanguis G9B cloned into the $\lambda \mathrm{gt} 11$ expression vector. The first BamHI site is located $5.53 \mathrm{~kb}$ downstream of the left end of the phage chromosome (Thanh et al., 1985).

from $S$. sanguis 12 (Ganeshkumar et al., 1988), and of the $30 \mathrm{kDa}$ protein cloned from FW213 by Fives-Taylor et al. (1987). The latter appears to be similar in size to a protein found in fimbriae isolated from S. sanguis FW213. We have found a cross-reaction between an antigen of FW213 and the adhesin of G9B. However, none of the polypeptides of the $80 \mathrm{kDa}$ antigen complex were detected in FW213, suggesting that the cross-reaction was due to other antigenic determinants (unpublished observations). These could be the glycosylated determinants which may form part of the adhesin in $S$. sanguis (Lamont et al., 1988b). The restriction map of the FW213 adhesin gene is also distinct from that of a $36 \mathrm{kDa}$ protein from $S$. sanguis 12, described by Ganeshkumar et al. (1988). Thus, at least three distinct adhesin genes have been identified in $S$. sanguis.

Since no obvious differences in numbers and types of fibrils between G9B and its nonadherent mutant $\left(\mathrm{Adh}^{-}\right)$have been found (P. S. Handley, personal communication), these appendages per se may not be responsible for the adhesion of $S$. sanguis to SHA. In addition, Wyatt et al. (1987) have found no correlation between the fibril density of a large number of $S$. sanguis strains and their adhesion to SHA. Adhesion among these strains may be more closely related to proteins associated with the fibrils or the longer fimbriae (Handley et al., 1985) but not covalently bound to them. This would account for the observations that surface molecules, including those with adhesin activity, can be extracted readily from oral streptococci by procedures which are not usually thought to disrupt covalent linkages (Lamont et al., 1988a; Ogier et al., 1984; A. S. Bleiweis, personal communication). The availability of $S$. sanguis adhesin genes will provide probes as well as the ability to produce sufficient quantities of adhesins and antibody reagents, which should aid in elucidating the specific functional domains of the adhesin molecules, their location on the cell surface and their salivary receptors.

This work was supported by US Public Health Service grant DE 03180 from the National Institutes of Health.

\section{REFERENCES}

Bergey, E. J., Levine, M. J., Reddy, M. S., BradWay, S. D. \& AL-Hashimi, I. (1986). Use of the photoaffinity cross-linking agent $N$-hydroxysuccinimidyl-4-azidosalicylic acid to characterize salivaryglycoprotein-bacterial interactions. Biochemical Journal 234, 43-48.

Cowan, M. M., Taylor, K. G. \& Doyle, R. J. (1986). Kinetic analysis of Streptococcus sanguis adhesion to artificial pellicle. Journal of Dental Research 65, 1278-1283.

Cowan, M. M., Taylor, K. G. \& Doyle, R. J. (1987). Energetics of the initial phase of adhesion of
Streptococcus sanguis to hydroxylapatite. Journal of Bacteriology 169, 2995-3000.

Curtiss, R., III, Murchison, H. M., Nesbitt, W. E., BarReTt, J. F. \& MichaleK, S. M. (1985). Use of mutants and gene cloning to identify and characterize colonization mechanisms of Streptococcus mutans. In Molecular Basis of Oral Microbial Adhesion, pp. 187-193. Edited by S. E. Mergenhagen \& B. Rosan. Washington, DC: American Society for Microbiology.

Douglas, C. W. I. \& Russell, R. R. B. (1984). Effect of specific antisera upon Streptococcus mutans 
adherence to saliva-coated hydroxyapatite. FEMS Microbiology Letters 25, 211-214.

Doyle, R. J., Nesbitt, W. E. \& TAYloR, K. G. (1982). On the mechanism of adherence of Streptococcus sanguis to hydroxylapatite. FEMS Microbiology Letters 15, 1-5.

EIfert, R., Rosan, B. \& Golub, E. (1984). Optimization of an hydroxyapatite adhesion assay for Streptococcus sanguis. Infection and Immunity 44, 287-291.

Elder, B. L. \& Fives-TAYloR, P. (1986). Characterization of monoclonal antibodies specific for adhesion: isolation of an adhesin of Streptococcus sanguis FW213. Infection and Immunity 54, 421-427.

Fachon-Kalweit, S., Elder, B. L. \& Fives-Taylor, P. (1985). Antibodies that bind to fimbriae block adhesion of Streptococcus sanguis to saliva-coated hydroxyapatite. Infection and Immunity 48, 617-624.

FaCKLaM, R. R. (1977). Physiological differentiation of viridans streptococci. Journal of Clinical Microbiology 5, 184-201.

FIVES-TAYLOR, P. (1982). Isolation and characterization of a Streptococcus sanguis FW213 mutant nonadherent to saliva-coated hydroxyapatite beads. In Microbiology-1982, pp. 206-209. Edited by D. Schlessinger. Washington, DC: American Society for Microbiology.

Fives-TAYloR, P. M. \& Thompson, D. W. (1985). Surface properties of Streptococcus sanguis FW213 mutants nonadherent to saliva-coated hydroxyapatite. Infection and Immunity 47, 752-759.

Fives-Taylor, P. M., Macrina, F. L., Pritchard, T. J. \& PEENE, S. S. (1987). Expression of Streptococcus sanguis antigens in Escherichia coli: cloning of a structural gene for adhesion fimbriae. Infection and Immunity 55, 123-128.

Ganeshoumar, N., Song, M. \& McBride, B. C. (1988). Cloning of a Streptococcus sanguis adhesin which mediates binding to saliva-coated hydroxyapatite. Infection and Immunity 56, 1150-1157.

Gibbons, R. J. \& van Houte, J. (1971). Selective bacterial adherence to oral epithelial surfaces and its role as an ecological determinant. Infection and Immunity 3, 567-573.

Gibbons, R. J., Moreno, E. C. \& Etherden, I. (1983). Concentration-dependent multiple binding sites on saliva-treated hydroxyapatite for Streptococcus sanguis. Infection and Immunity 39, 280-289.

HaMada, S. \& Slade, H. D. (1980). Biology, immunology, and cariogenicity of Streptococcus mutans. Microbiological Reviews 44, 331-384.

Handley, P. S., Carter, P. L., Wyatt, J. E. \& HESKETH, L. M. (1985). Surface structures (peritrichous fibrils and tufts of fibrils) found on Streptococcus sanguis strains may be related to their ability to coaggregate with other oral genera. Infection and Immunity 47, 217-227.

LAEMMLI, U. K. (1970). Cleavage of structural proteins during the assembly of the head of bacteriophage T4. Nature, London 227, 680-685.

LAMONT, R. J., Rosan, B., Murphy, G. M. \& BAKER, C. T. (1988a). Streptococcus sanguis surface antigens and their interactions with saliva. Infection and Immunity 56, 64-70.

Lamont, R. J., Rosan, B., Baker, C. T. \& Murphy, G. M. $(1988 b)$. Characterization of an adhesin antigen of Streptococcus sanguis G9B. Infection and Immunity 56, 2417-2423.

Liljemark, W. F. \& Bloomquist, C. G. (1981). Isolation of a protein-containing cell surface component from Streptococcus sanguis which affects its adherence to saliva-coated hydroxyapatite. Infection and Immunity 34, 428-434.

Maniatis, T., Fritsch, E. F. \& Sambrook, J. (1982). Molecular Cloning: a Laboratory Manual. Cold Spring Harbor, NY: Cold Spring Harbor Laboratory.

Morris, E. J. \& MCBride, B. C. (1984). Adherence of Streptococcus sanguis to saliva-coated hydroxyapatite: evidence for two binding sites. Infection and Immunity 43, 656-663.

Morris, E. J., Ganeshiumar, N. \& McBride, B. C. (1985). Cell surface components of Streptococcus sanguis: relationship to aggregation, adherence, and hydrophobicity. Journal of Bacteriology 164, 255262.

Morris, E. J., Ganeshiumar, N., Song, M. \& MCBRIDE, B. C. (1987). Identification and preliminary characterization of a Streptococcus sanguis fibrillar glycoprotein. Journal of Bacteriology 169, 164-171.

Ogier, J. A., Klein, J. P., Sommer, P. \& Frank, R. M. (1984). Identification and preliminary characterization of saliva-interacting surface antigens of Streptococcus mutans by immunoblotting, ligand blotting, and immunoprecipitation. Infection and Immunity 45, $107-112$.

Olmsted, J. B. (1981). Affinity purification of antibodies from diazotized paper blots of heterogeneous protein samples. Journal of Biological Chemistry 256, 1 1955-11957.

Rosan, B. (1973). Antigens of Streptococcus sanguis. Infection and Immunity 7, 205-211.

RosAN, B. (1976). Relationship of cell wall composition of group H streptococci and Streptococcus sanguis to their serological properties. Infection and Immunity 13, 1144-1153.

Rosan, B. (1978). A comparison of the phenol water and Rantz and Randall teichoic acid antigens in Group $\mathrm{H}$ streptococci. In Secretory Immunity and Infection, pp. 791-802. Edited by J. R. McGhee, J. Mestecky \& J. L. Babb. New York: Plenum.

Rosan, B., Appelbaum, B., Campbell, L. K., Knox, K. W. \& WICKEN, A. J. (1982). Chemostat studies of the effect of environmental control on Streptococcus sanguis adherence to hydroxyapatite. Infection and Immunity 35, 64-70.

Rosan, B., EIFERT, R. \& Golub, E. (1985). Bacterial surfaces, salivary pellicles, and plaque formation. In Molecular Basis of Oral Microbial Adhesion, pp. 69 76. Edited by S. E. Mergenhagen \& B. Rosan. Washington, DC: American Society for Microbiology.

Thanh, V. H., Young, R. A. \& Davis, R. W. (1985). Constructing and screening cDNA libraries in $\lambda \mathrm{gt} 10$ and $\lambda$ gt11. In DNA Cloning: a Practical Approach, vol. 1, pp. 49-78. Edited by D. M. Glover. Oxford: IRL Press.

Towbin, H., Staehelin, T. \& Gordon, J. (1979). Electrophoretic transfer of proteins from polyacrylamide gels to nitrocellulose sheets: procedure and some applications. Proceedings of the National 
Academy of Sciences of the United States of America 76, 4350-4354.

Wyatt, J. E., Hesketh, L. M. \& Handley, P. S. (1987). Lack of correlation between, fibrils, hydrophobicity, and adhesion for strains of Streptococcus sanguis biotypes I and II. Microbios 50, 7-15.

Young, R. A. \& DAvis, R. W. (1983). Efficient isolation of genes by using antibody probes. Proceed- ings of the National Academy of Sciences of the United States of America 80, 1194-1198.

Young, R. A., Bloom, B. R., Grosskinsky, C. M., Ivanyi, J., Thomas, D. \& Davis, R. W. (1985). Dissection of Mycobacterium tuberculosis antigens using recombinant DNA. Proceedings of the National Academy of Sciences of the United States of America 82, 2583-2587. 